\title{
NUEVAS ATRIBUCIONES DE ESCULTURA GENOVESA EN EL SUR DE ESPAÑA
}

\author{
NEW ATTRIBUTIONS OF GENOESE SCULPTURE \\ IN SOUTHERN SPAIN
}

\author{
José Miguel SÁnchez Peña \\ Museo de Cádiz. España \\ hout.mg@gmail.com
}

\begin{abstract}
El presente estudio trata en líneas generales de la llegada a Cádiz y a otros lugares de la provincia y de Andalucía, en el siglo XVIII, de esculturas de madera policromada de procedencia genovesa. Pero también, y a lo largo de esa centuria, llegan a Cádiz escultores genoveses que se asientan en la ciudad instalando sus talleres y realizando esculturas. Las obras de estos adquieren enseguida una gran fama y difusión, y tienen como destino no solo la ciudad de Cádiz, sino también diversos puntos de Andalucía.

Palabras clave: Génova; escultura policromada; Barroco; Cádiz; siglo XVIII.
\end{abstract}

The present study deals in general terms with the arrival in Cádiz and other places of the province and Andalusia of polychrome wooden sculptures of Genoese origin in the $18^{\text {th }}$ century. But also, and throughout that century, Genoese sculptors arrive in Cádiz installing their workshops and making sculptures. The works of these acquire immediately a great fame and diffusion, and they have like destiny not only the city of Cádiz, but also diverse points of Andalusia.

Keywords: Genoa; polychrome sculpture; Baroque; Cádiz; $18^{\text {th }}$ century.

\section{INTRODUCCIÓN}

La existencia de esculturas lígneas de procedencia genovesa en la ciudad de Cádiz es un hecho ya estudiado y documentado; fue el historiador Hipólito Sancho de Sopranis pionero en el tema, al abordarlo con una serie de artículos en el periódico La Información del Lunes, que se editaba en Cádiz ese día de la semana a mediados del siglo pasado ${ }^{1}$. Le siguió el historiador Enrique Hormigo Sánchez,

${ }^{1}$ Los artículos citados se publicaron en La Información del Lunes en 1958, dentro de una serie dedicada al arte en Cádiz. 
quien aporta información sobre artistas genoveses y saca a la luz al desconocido Domingo Giscardi, uno de los escultores genoveses con mayor número de obras en Cádiz ${ }^{2}$. Años después, se trata el tema con mayor profundidad con sendos estudios publicados en Génova (1991) ${ }^{3}$ y en Cádiz (2006) ${ }^{4}$, a los que siguen artículos en prensa y revistas como resultado de la continua aparición o identificación de esculturas genovesas.

Un selecto y no muy abundante número de estas esculturas policromadas comenzaron a llegar desde Génova en el primer tercio del siglo XVIII, y no solamente a Cádiz, sino también a diversos lugares de la provincia e incluso de Andalucía. Como ejemplos destacados tenemos en la capital el Arcángel San Rafael de la iglesia de San Juan de Dios ${ }^{5}$ y la Virgen del Carmen de Portacoeli, del convento del Carmen ${ }^{6}$; en San Fernando (Cádiz), el Crucifijo de la Salud ${ }^{7}$ y la imagen de San José con el Niño ${ }^{8}$, en el convento del Carmen de esta ciudad; y, en Antequera (Málaga), en la iglesia de San Pedro, una imagen de la Inmaculada ${ }^{9}$. En fechas más recientes hemos identificado varias imágenes de procedencia genovesa: en el convento de las carmelitas descalzas de Sanlúcar de Barrameda (Cádiz), una

${ }^{2}$ HORMIGO SÁNCHEZ, Enrique: "Las obras en Cádiz del escultor genovés Domingo Giscardi", Anales de la Real Academia de Bellas Artes de Cádiz, 4, 1986, pp. 87-95.

3 ARANDA LINARES, Carmen; HORMIGO SÁNCHEZ, Enrique y SÁNCHEZ PEÑA, José Miguel: Scultura lignea genovesa a cadice nel settecento. Opere e documenti. Génova, 1993.

${ }^{4}$ SÁNCHEZ PEÑA, José Miguel: Escultura Genovesa. Artífices del Setecientos en Cádiz. Cádiz, 2006.

5 Ibidem, pp. 98-100.

${ }^{6}$ Además de estas dos obras citadas, la primera por el historiador Ratti, tenemos las imágenes de San Francisco de Asís y de San Jerónimo en la capilla del Pilar de San Lorenzo, entre otras imágenes importadas. ARANDA LINARES, Carmen; HORMIGO SÁNCHEZ, Enrique y SÁNCHEZ PEÑA, José Miguel: Scultura lignea..., op. cit., pp. 69-70; FRANCHINI GUELFI, Fausta: "Documenti per la Scultura Genovese del Settecento", Atti della Società Ligure di Storia Patria (Nuova Serie), XXIX (CIII), Fasc. I, 1989, pp. 425-446; y SÁNCHEZ PEÑA, José Miguel: Escultura Genovesa..., op. cit., pp. 101-103.

${ }^{7}$ ARANDA LINARES, Carmen; HORMIGO SÁNCHEZ, Enrique y SÁNCHEZ PEÑA, José Miguel: Scultura lignea..., op. cit., p. 68; MANZANO BELTRÁN, Pedro: "El Cristo de la Salud", en Iconografía y Arte Carmelitanos. Madrid, 1991, p. 144; SÁNCHEZ PEÑA, José Miguel: Escultura Genovesa..., op. cit., pp. 100-101; y SANGUINETI, Daniele: Antón María Maragliano. Génova, 1998, p. 191.

${ }^{8}$ MANZANO BELTRÁN, Pedro: "Breves noticias sobre esculturas italianas en la iglesia conventual de Ntra. Sra. del Carmen de San Fernando (Cádiz)", Anales de la Real Academia de Bellas Artes de Cádiz, 8, 1990, pp. 119-129.

9 ROMERO TORRES, José Luis: "Inmaculada", en Tota Pulchra (El Arte de la Iglesia de Málaga). Málaga, 2005, p. 222. 
Inmaculada ${ }^{10}$; en la catedral de Jerez, otra imagen de la Inmaculada ${ }^{11}$; en Puente Genil (Córdoba), una Virgen de los Ángeles ${ }^{12}$, y, en la iglesia de San Mateo de Tarifa, una imagen de San Francisco de factura y procedencia genovesa, una obra de gran calidad que adscribimos al taller de Anton María Maragliano ${ }^{13}$ (Figura 1). Son algunos ejemplos concretos, cuyo elenco a buen seguro se irá ampliando con el paso de los años.

En el tercio central del siglo XVIII, tras el fallecimiento de Maragliano, se produce la llegada a Cádiz de un elevado número de escultores ligures que se establecen en la ciudad. En realidad son continuadores del estilo y la técnica de Maragliano; a ello hay que añadir la descendencia de estos artistas, nacidos en Cádiz, hijos de padres genoveses, lo que garantizaba una continuación de los talleres.

Del mismo modo que llegan esculturas procedentes de Génova, como ya hemos citado anteriormente, muchas obras realizadas en Cádiz por los artistas genoveses tienen como destino diversos puntos no solo de la provincia sino también de Andalucía. Podemos hablar de casos concretos como el Crucificado y las tallas de pequeño formato de San Servando y San Germán de la ermita de la Oliva de Vejer de la Frontera (Cádiz) ${ }^{14}$. En la parroquial de Nuestra Señora de la O de Rota (Cádiz), se encuentra una Sagrada Familia, obra de tamaño académico del genovés Domingo Giscadi ${ }^{15}$, autor también de la imagen de Santa Ana con la Virgen niña de la ermita con esa advocación de Chiclana (Cádiz) ${ }^{16}$. En el convento de los capuchinos de Sanlúcar de Barrameda (Cádiz), se venera una destacada imagen de San Antonio de Padua con el Niño, que procede de la localidad de San Fernando. Es obra del escultor nacido en Cádiz, hijo de padres genoveses, Juan Gandulfo ${ }^{17}$ (Figura 2). Recordemos que el escultor Juan Gandulfo realizó diversas obras para la iglesia mayor de San Pedro y San Pablo de esa misma ciudad. También debió de gozar de cierto prestigio cuando realizó trabajos para el

${ }^{10}$ SÁNCHEZ PEÑA, José Miguel: "Esculturas Genovesas en Cádiz", Anales de la Real Academia de Bellas Artes de Cádiz, 13, 1995, pp. 165-170.

${ }^{11}$ SÁNCHEZ PEÑA, José Miguel: "Una Inmaculada genovesa en la Catedral de Jerez”, Diario de Cádiz, 28-12-2015, p. 47.

12 SÁNCHEZ PEÑA, José Miguel: Escultura Genovesa ..., op. cit., pp. 106-107.

${ }^{13}$ Hace años identifiqué esta imagen como obra del taller de Maragliano, cuya información trasladé al profesor Daniele Sanguineti, que la dio a conocer. Procede de un convento desaparecido de Tarifa. SANGUINETI, Daniele: Anton Maria Maragliano 1664-1739. Génova, 2012, p. 338; y PATRÓN SANDOVAL, Juan Antonio: "El Convento Franciscano de San Juan de Prado", Aljaranda, 54, 2004, p. 29.

${ }^{14}$ SÁNCHEZ PEÑA, José Miguel: Escultura Genovesa..., op. cit., pp. 159-160.

${ }^{15}$ Ibidem, p. 146.

${ }^{16}$ Ibid., p. 130.

${ }^{17} \mathrm{http} / / /$ www.islapasion.net/arteehistoria/hermandadesextinguidas_mosig27.html; y SÁNCHEZ PEÑA, José Miguel: Escultura Genovesa..., op. cit., pp. 170-182. 
oratorio de la Santa Cueva de Cádiz. Al mismo tiempo aparece registrado como perito, tasando junto a otras personas -relojero, pintor, mercader de libros, etc.en el reparto de bienes de don Marcelino Martínez Junquera en Cádiz, figurando como maestro escultor ${ }^{18}$.

Las esculturas realizadas por los maestros genoveses tienen todas unas características comunes, formales, estilísticas y sobre todo técnicas, que las diferencian del resto de las escuelas coetáneas ${ }^{19}$. Las imágenes que llegan de la Liguria están ejecutadas la mayoría en madera de tilo, e incluso en abedul, utilizándose grandes bloques o troncos, o, lo que es lo mismo, tablones de gran escuadría. Las que ejecutan los artistas ligures en Cádiz se hallan realizadas en madera de cedro, que era un tipo de madera muy abundante en Cádiz en esa época, procedente de las Indias, y en algunos casos en madera de ciprés según hemos comprobado. Cuando a finales de la centuria escasea el cedro, ya que decae la importación de maderas de las Indias, se utiliza el pino. El tilo es una madera muy propensa a ser atacada por los xilófagos en climas húmedos y calurosos. El cedro, al contrario, es indemne ante este problema, muy apto para la talla, pero en algunos casos puntuales presenta "la pudrición parda", producida por un hongo y la acción de la humedad unida a los ambientes calurosos, húmedos, oscuros y con poca ventilación. Los escultores genoveses utilizan ojos de cristal -cuarto de esfera-, que van colocados por el exterior, y se superponen los párpados de pasta. En las imágenes de talla completa se observan estofados de gran riqueza polícroma, con abundancia de la técnica de "la barbotina", en relieve. Esta labor la realizan de forma indiferente tanto doradores genoveses como españoles residentes en Cádiz, alcanzando altas cotas de calidad y maestría como puede comprobarse.

Finalmente hemos de decir que la aparición de esculturas, especialmente las de pequeño formato, es continua y van identificándose muchas obras. En este sentido hacemos diversas propuestas de atribución de una serie de esculturas polícromas que hemos ido identificando desde hace tiempo.

18 AHPC (Archivo Histórico Provincial de Cádiz), leg. 1869, s. f., 19-2-1777.

${ }_{19}$ Para más información sobre la técnica de la escultura genovesa, véase ARANDA LINARES, Carmen; HORMIGO SÁNCHEZ, Enrique y SÁNCHEZ PEÑA, José Miguel: Scultura lignea..., op. cit., pp. 49-58; SÁNCHEZ PEÑA, José Miguel: Escultura Genovesa..., op. cit., pp. 59-75; y SANGUINETI, Daniele: Anton Maria Maragliano, op. cit., pp. 88-96 y 141-160. 


\section{NUEVAS ATRIBUCIONES}

\section{San Antonio de Padua con el Niño. Santa Iglesia Catedral, Cádiz}

Son muy escasos los datos que poseemos de esta imagen, al no haber constancia documental en los inventarios de su fecha de entrada en la catedral, pero es muy posible que proceda del desamortizado y luego destruido templo de los franciscanos descalzos (Figura 3). Hay reseñas documentales de que un buen número de esculturas de la catedral llegaron procedentes de este convento, que fue derribado al poco tiempo. Diversos historiadores que describen todos los altares de la catedral no citan esta imagen; otros, como Ángel Mozo y Rafael Ortega, afirman que procede de la cartuja de Jerez; y en 1960 se encontraba expuesta en el entonces Museo de la Catedral, en la sala de la Concepción. Sin embargo, no hemos podido verificar esta supuesta procedencia ${ }^{20}$.

En la fotografía que ilustra el artículo, aparece la imagen en un precario estado de conservación; después fue intervenida de una forma poco ortodoxa o respetuosa. Para su adscripción a talleres genoveses nos basamos en el estudio de su técnica y en el estilo de la obra. Se trata de una talla de tamaño académico, de madera de tilo y maciza. Los bloques de madera, una vez encolados y ensamblados, se refuerzan con clavos de forja. Se puede observar el grado de deterioro causado por insectos xilófagos, algo habitual en este tipo de maderas y en esculturas procedentes de Italia. Se aprecian pérdidas volumétricas importantes, que afectan no solo a la talla, sino también a la policromía. La imagen tiene ojos de cristal colocados por el exterior con los párpados de pasta.

La composición general, con la imagen del santo arrodillado, inclinándose sobre la figura del Niño Jesús al que besa su mano izquierda, ha sido muy repetida por los maestros ligures. Conviene tener presente los grandes altorrelieves creados por Maragliano para las iglesias genovesas de la Annunziata del Vastato y la de los padres capuchinos, entre otras.

La figura gravita sobre un conjunto de nubes plateadas ${ }^{21}$ que van ascendiendo por la parte delantera izquierda y sirven de apoyo al Niño Jesús, cuando se le aparece al santo lisboeta. En la parte baja delante del santo aparece un libro abierto -formando parte de la talla-, que constituye con las azucenas el símbolo del santo. Tanto en el rostro del santo y en la talla del cabello, como en las manos y pies, se hacen patentes los inconfundibles rasgos maraglianescos, como la boca pequeña y cerrada, ojos algo separados del eje central del rostro y talla del cabello de corte y surco minucioso. Es muy destacable el estudio de la túnica o

${ }^{20}$ MOZO POLO, Ángel y ORTEGA BEY, Rafael: La Catedral de Cádiz (Guía Artística). Cádiz, 1960, pp. 32 y 35.

${ }^{21}$ El plateado de las nubes está hecho sobre yeso y bol, al agua, con la misma técnica con la que se utiliza el pan de oro. 
hábito; los paños van formando grandes volúmenes y pliegues que caen con gran naturalidad.

La policromía que luce el hábito del santo lisboeta, esgrafiado el estofado imitando una tela de sarga o estameña, en tonos pardos grisáceos, quizás pueda relacionarse con el hábito de los franciscanos descalzos, gris azulado. De hecho, existen en Cádiz algunas imágenes de San Francisco y de santos franciscanos de candelero para vestir con valiosas túnicas bordadas en ese color.

Crucificado. Convento de franciscanas concepcionistas de la Piedad (Descalzas), Cádiz

Este Crucificado de pequeño formato $(30 \mathrm{~cm}$ de cabeza a pies aproximadamente) es uno más de la colección existente en el convento de las Descalzas, y se halla en la clausura del monasterio (Figura 4). Era frecuente en los conventos de clausura que cada religiosa tuviese uno en su celda. Como decimos, el Crucificado presenta todos los rasgos morfológicos y técnicos de la escuela genovesa. Representa a Cristo muerto, clavado en una cruz arbórea - de origen aún-por tres clavos, y su anatomía -sobre todo el torso- recuerda al Crucificado de la Piedad de la iglesia de Santiago (Cádiz). El planteamiento general arqueado, con centro a su derecha, lo repiten la mayoría de los Crucificados de escuela genovesa existentes en Cádiz, comenzando por el de la Vera Cruz. Sin embargo, los conservados en la Liguria, obras de Antón María Maragliano y su escuela, en su mayoría el esquema que presentan es a la inversa, es decir, el centro del arco está a su izquierda. El sudario presenta disposición triangular, del que cuelgan en los laterales unos pliegues, pero parcialmente mutilado el del lado derecho del Crucifijo.

El Crucificado se encuentra anclado en un montículo o calvario, también de origen, de caracteres análogos a la cruz, en donde aparece la serpiente. Tanto la cruz como el montículo nos deben servir de modelo por ser obras originales, pues muchas cruces, siendo piezas complementarias tan importantes, han sido sustituidas.

La mayoría de los Crucificados que abundan por los templos gaditanos de estas características suelen atribuirse a Francisco María Mayo, no solo por su parecido al Crucificado de la Piedad, sino también por ser este escultor uno de los pocos que tienen documentado un Crucificado, exceptuando a Giscardi y a Gandulfo. No obstante, debemos actuar con cautela y no precipitarnos en formular una atribución en concreto porque aún hay muchos escultores identificados de los que no conocemos obras, y esculturas que aún permanecen en el anonimato. La talla presenta un excelente estado de conservación que no ha sido alterado. 
Calvario. Iglesia de los Desamparados, Sanlúcar de Barrameda (Cádiz)

Componen este grupo escultórico, que en Andalucía conocemos como "un Calvario", la imagen del Crucificado que lo preside y, a sus pies, la Virgen, San Juan y María Magdalena en la capilla de los Desamparados de Sanlúcar de Barrameda (Cádiz) (Figuras 4-5). Las imágenes se hallan dentro de una vitrina protegida con un cristal, lo que ha contribuido a su perfecta conservación, en el testero del evangelio y a los pies del templo. Afortunadamente, el conjunto se encuentra intacto, sin intervenciones de ningún tipo, incluidos los bordados de las imágenes secundarias, que parecen ser los originales de mediados del siglo XVIII.

Es frecuente encontrar en los templos gaditanos, sobre todo en sacristías y dependencias internas, estos grupos escultóricos; por citar un ejemplo, el existente en la Santa Cueva. También abundas estas imágenes de pequeño formato, la mayoría pasionistas, que pertenecían a cofradías penitenciales. Se conocían como "enfermeras", pues se llevaban a los domicilios de los hermanos cuando las solicitaban por encontrarse enfermos. Aún en el día de hoy se sigue esta costumbre en algunos casos.

Comenzando con el análisis del Crucificado, vamos a realizar un estudio comparativo con el reseñado anteriormente del convento de las Descalzas (Cádiz); comparten dimensiones, idéntico estilo en las cruces, arbóreas y originales ambas. Respecto a las bases o peanas, nos encontramos con ese típico empedrado rocoso tan característico de los maestros genoveses que evidencian la misma autoría. Los cuerpos de los Crucificados, con el movimiento arqueado, guardan estrecho parecido en su morfología anatómica. Los sudarios presentan las mismas disposiciones de plegados y volúmenes. Las policromías, detallistas y netamente genovesas, con los mismos surcos de sangre y llagas. Las imágenes que le acompañan, la Virgen, San Juan y la Magdalena, son tallas de candelero para vestir. Resulta curiosa la imagen de la Virgen que calza zapatos, algo frecuente en algunas escuelas mediterráneas. Por su curiosidad, la imagen de la Magdalena tiene el cabello tallado, pero lo combina en parte con cabello natural que cae por la espalda.

Tanto la cruz arbórea, como el peanón o montículo, son similares al de las Descalzas, de origen también.

\section{San Juan Evangelista. Iglesia de la Divina Pastora, Cádiz}

En esta obra nos referimos exclusivamente a la cabeza, que fue adaptada a un cuerpo o candelero para vestir (Figura 6). Es una imagen que perteneció a la cofradía del Perdón (parroquia de Santa Cruz, Cádiz), y dejó de utilizarse cuando el escultor Luis Ortega Bru hizo la que posee la hermandad en propiedad. De siempre ha figurado como obra del imaginero gaditano Miguel Láinez Capote $(\dagger 1980)$, pero examinado el rostro de la talla vemos que sería una imagen antigua -posiblemente algún santo- adaptada por el escultor para esta iconografía. 
El citado imaginero gaditano apenas tuvo imágenes de creación propia, pues la mayoría de sus obras eran realmente adaptaciones o transformaciones de otras.

No cabe duda de que el rostro es plenamente representativo de la estética genovesa, por sus rasgos, la forma de tallar y componer el cabello, y la colocación de los ojos de cristal por el exterior. Posiblemente fuese una obra importada, pensada para vestir, de la que solamente conservamos la cabeza, que fue reaprovechada como ya hemos apuntado. Tiene un rostro de gran expresividad, destacando la talla del cabello formando bucles.

Presenta un deficiente estado de conservación, con rastros de xilófagos, lo que nos hace pensar en maderas de origen ligur, presuntamente madera de tilo. Afortunadamente, la cabeza no ha sido transformada o alterada, pero presenta una policromía plana, sin matices, que realmente es un repinte generalizado que empobrece la calidad de la talla.

En la actualidad se encuentra depositado en la iglesia de la Pastora (Cádiz), en un retablo del lado del evangelio junto al Crucificado del Buen Viaje, estando también la antigua Dolorosa de la cofradía del Perdón.

Virgen con el Niño. Iglesia parroquial de San Jorge,

Alcalá de los Gazules (Cádiz)

La imagen de la Virgen con el Niño que preside en la actualidad un retablo en el crucero, lado del evangelio, de la parroquia de San Jorge de Alcalá de los Gazules (Cádiz) parece ser que procede del extinto convento de Santo Domingo de la misma localidad ${ }^{22}$ (Figura 7). Se trata de una talla que por sus rasgos morfológicos, técnicos y estilísticos podemos atribuir al escultor genovés Domingo Giscardi ${ }^{23}$.

La imagen de la Virgen aparece sosteniendo al Niño con su mano izquierda, como es usual en las imágenes de esta temática de escuela genovesa, mientras que en la derecha sostiene un cetro. El conjunto se sitúa sobre un trono de nubes, y en la imagen son visibles los pies, que calzan sandalias, siguiendo la secular costumbre de los maestros italianos. La cabeza se cubre parcialmente con un tocado, y el manto descansa sobre el hombro izquierdo; la figura destaca por su actitud hierática. Los ropajes, túnica carmín y manto azul, con rica decoración estofada y policromada, ofrecen plegados que dejan entrever volúmenes, como brazos y

${ }^{22}$ El examen de la imagen se ha hecho con la misma colocada en el altar, lo que no ha permitido verla de cerca, y no hemos podido averiguar el tipo de madera que se utilizó, que suponemos será cedro. Mide un metro de altura aproximadamente. Agradecemos a don Gabriel y a don Ismael Almagro Montes de Oca la información y facilidades otorgadas para fotografiar y estudiar esta imagen.

${ }^{23}$ SÁNCHEZ PEÑA, José Miguel: Escultura Genovesa..., op. cit., pp. 125-146. 
piernas. La figura del Niño aparece bendiciendo con su mano derecha, mientras que con la izquierda sostiene el globo terráqueo rematado con la cruz.

Ambas imágenes repiten conocidos modelos del escultor, tanto en los rostros como en la indumentaria de la Virgen. De hecho, el rostro recuerda a los de las imágenes de los grupos de Tobías y el Ángel existentes en las iglesias gaditanas de Santiago y San Antonio. En cuanto a la figura del Niño, la talla y disposición del cabello nos remite a los ángeles lampareros de la Palma o los del Sagrario de San Francisco, ambos en Cádiz.

Fecha de recepción: 30 de septiembre de 2018

Fecha de aceptación: 1 de julio de 2019 


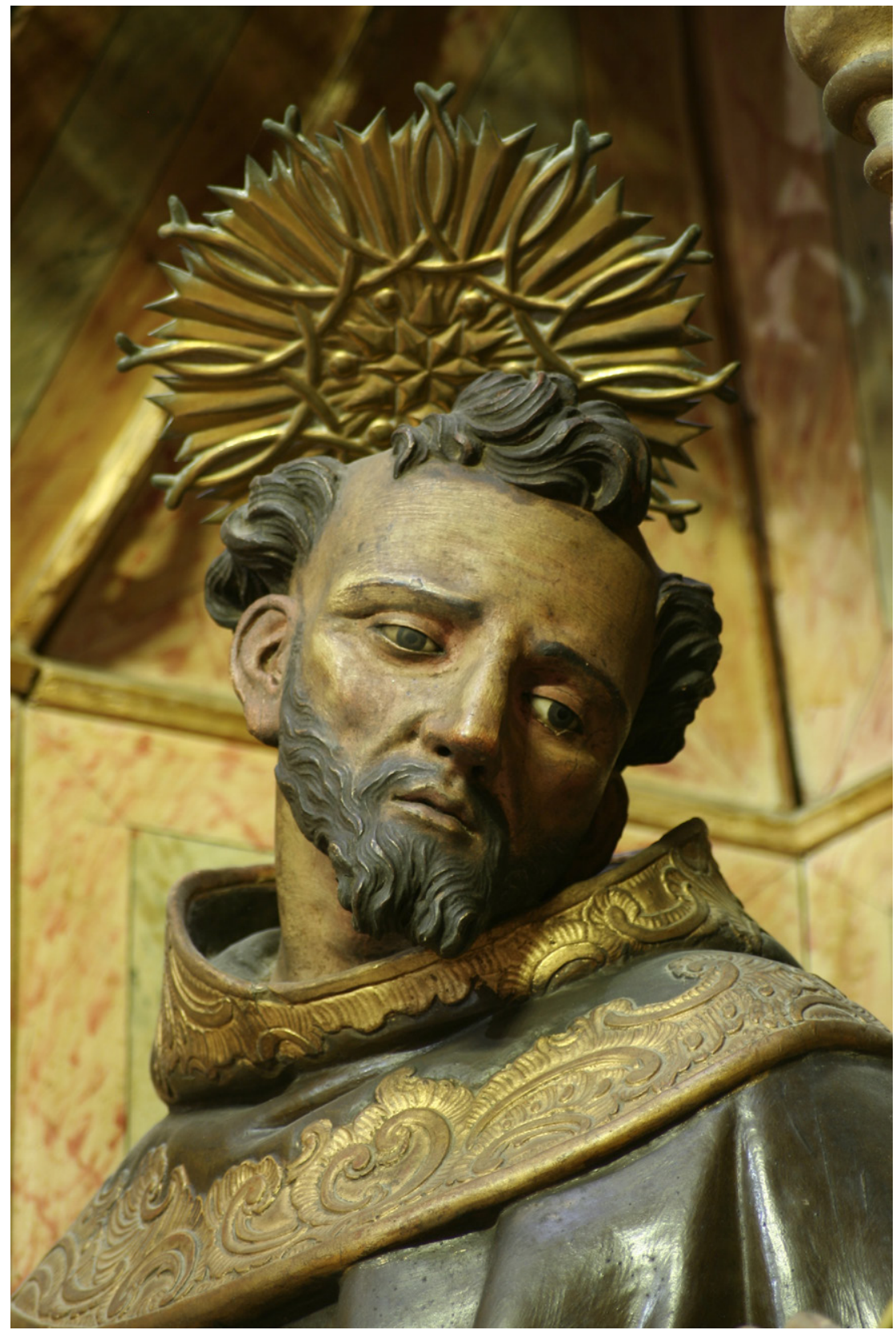

Figura 1. San Francisco de Asís, iglesia de San Mateo, Tarifa (Cádiz).

LABORATORIO DE ARTE 31 (2019), pp. 441-454, ISSN 1130-5762

e-ISSN 2253-8305 - DOI http://dx.doi.org/10.12795/LA.2019.i31.25 


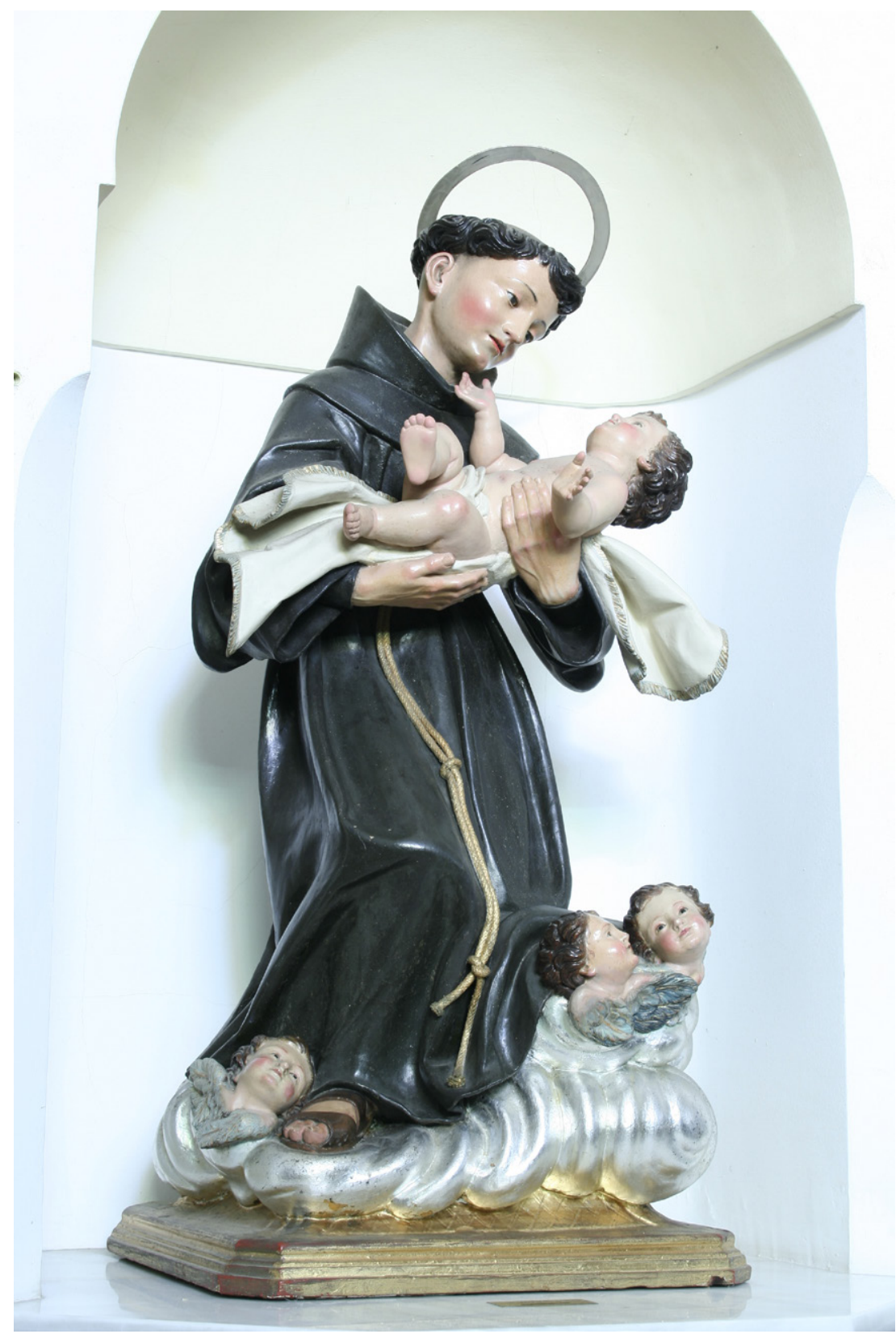

Figura 2. San Antonio de Padua, convento de padres capuchinos, Sanlúcar de Barrameda (Cádiz). 


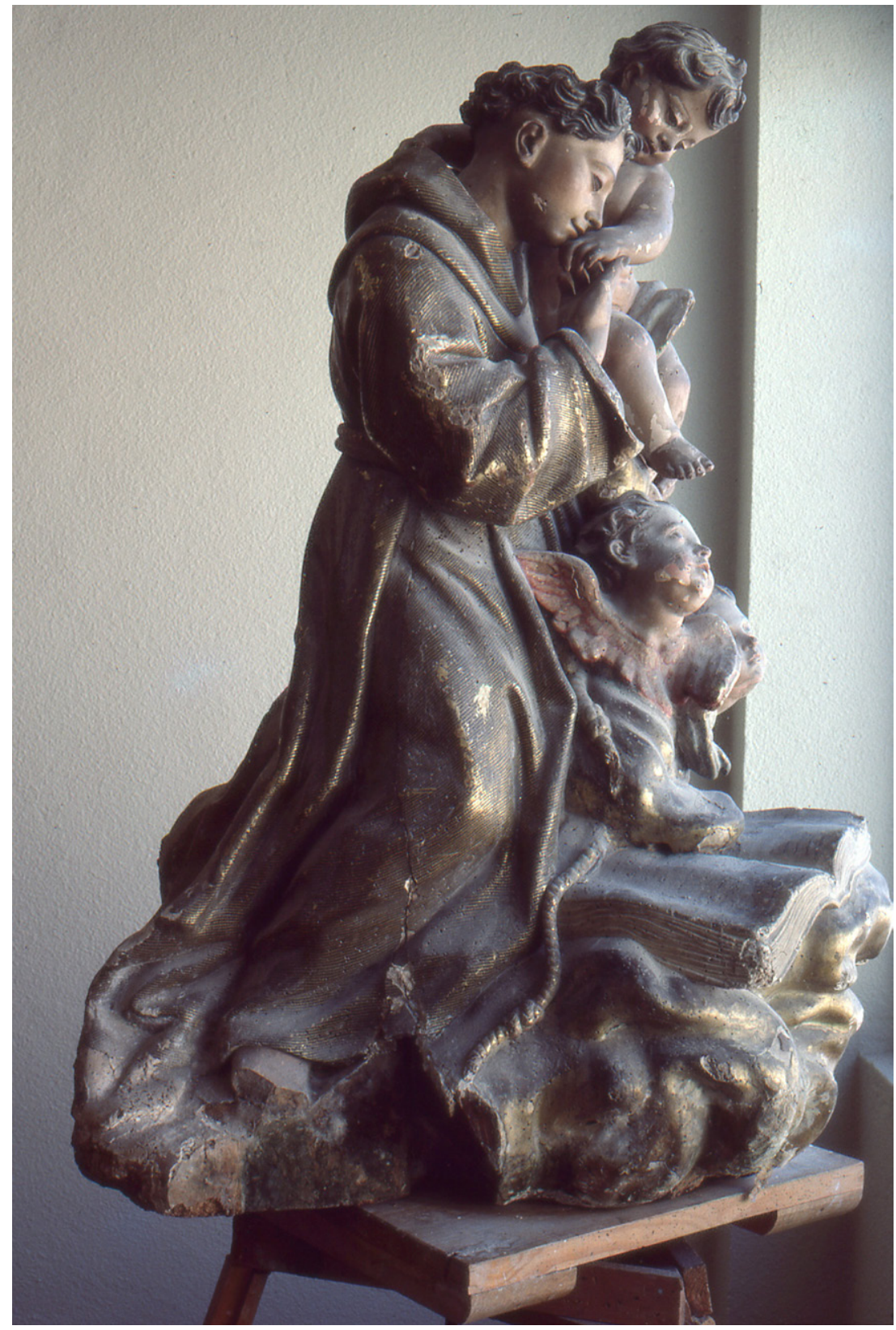

Figura 3. San Antonio de Padua, catedral de Cádiz. 


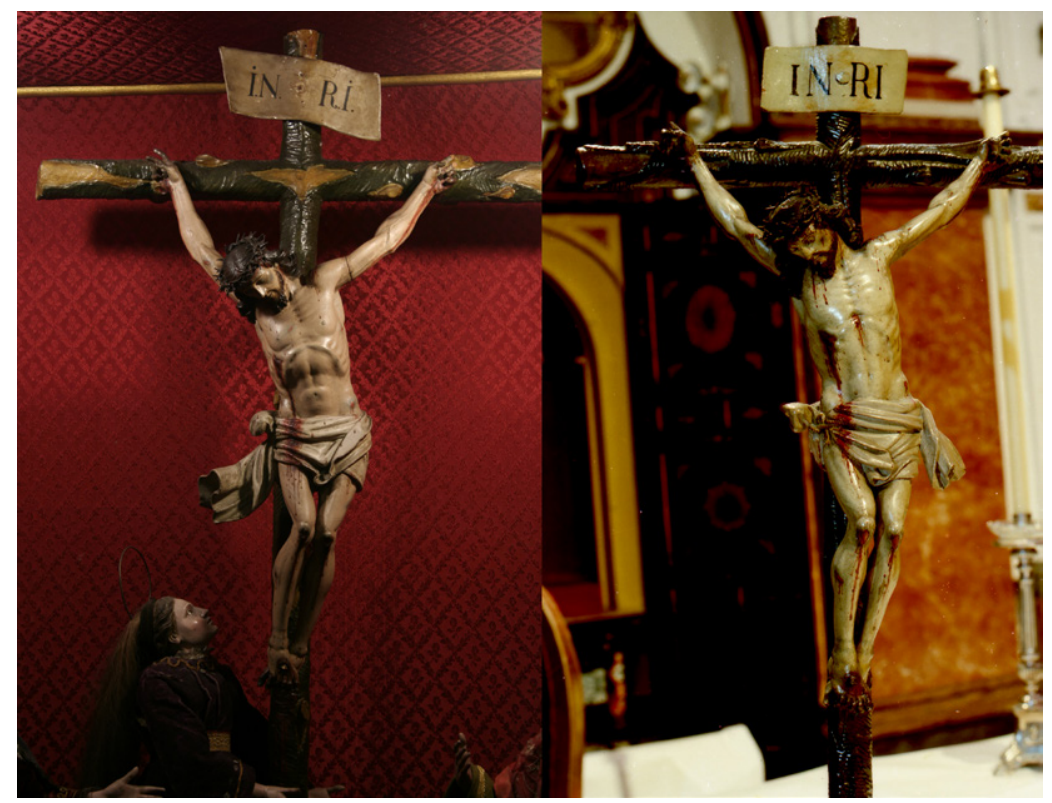

Figura 4. Foto comparativa de los Crucificados de la iglesia de los Desamparados de Sanlúcar de Barrameda (Cádiz) y de las Descalzas de Cádiz.

Figura 5. Calvario, iglesia de los Desamparados, Sanlúcar de Barrameda (Cádiz).

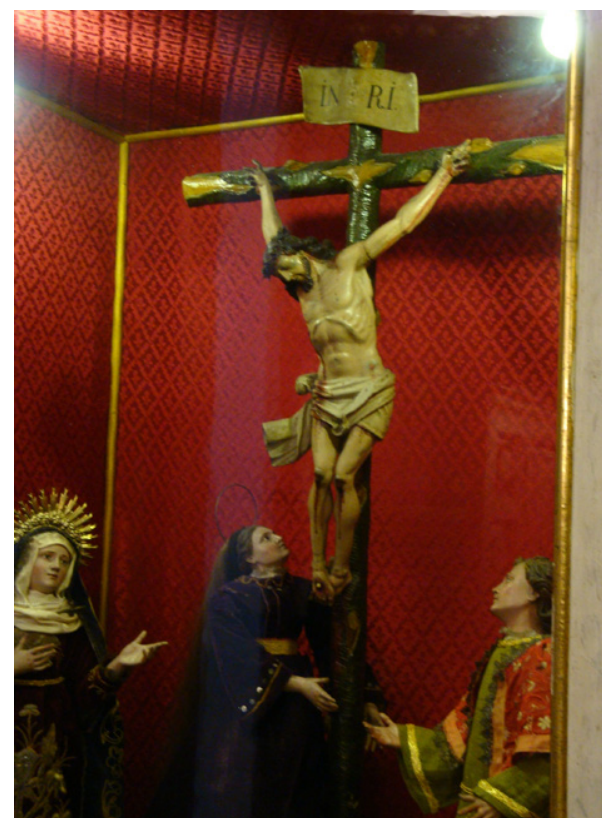




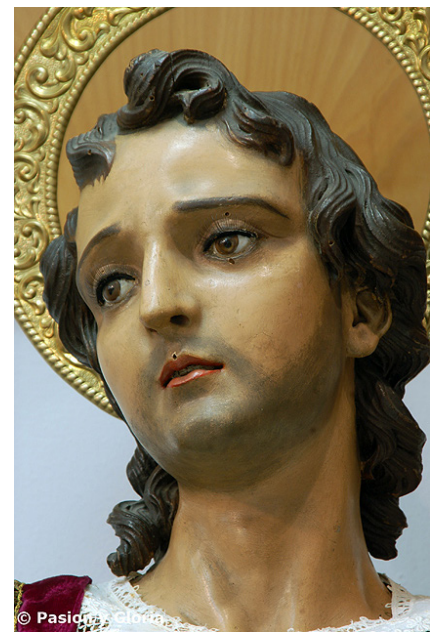

Figura 6. San Juan Evangelista, iglesia de la Pastora, Cádiz. Foto: Jesús Guerrero Alba

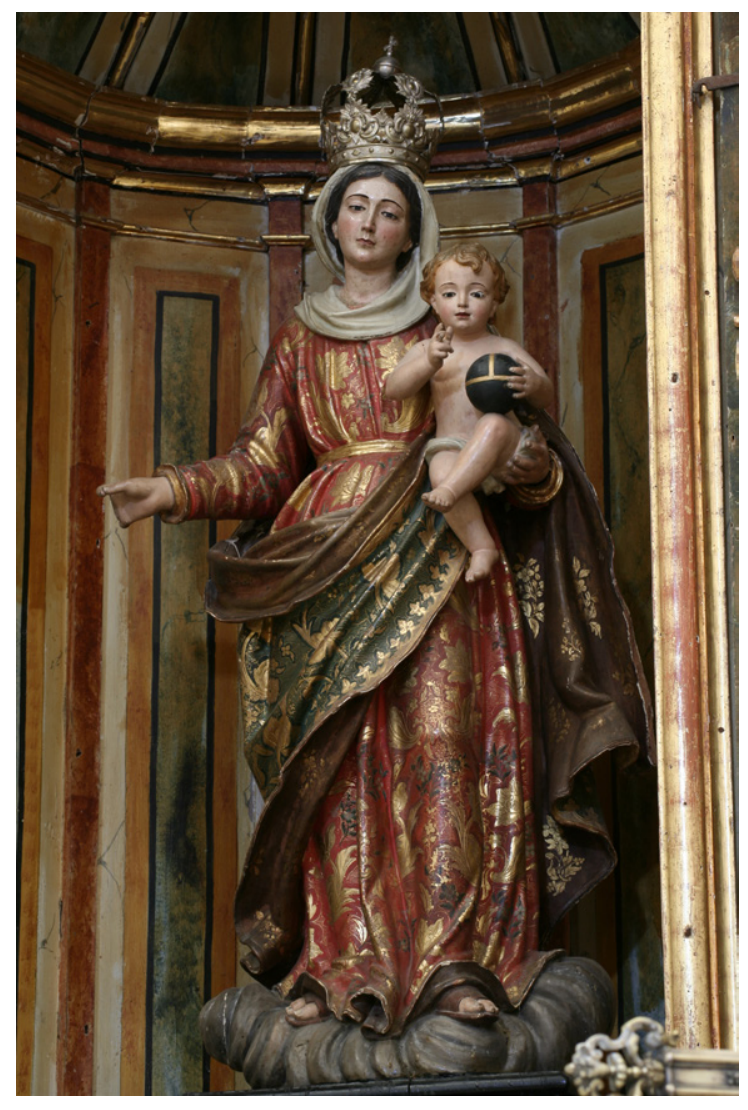

Figura 7. Virgen con el Niño, iglesia de San Jorge, Alcalá de los Gazules (Cádiz). 